\title{
Nutritional Status of Adolescents from High Socio-Economic Strata in Delhi
}

\author{
Manjot Kaur ${ }^{1}$ and Meenu Aggarwal2 ${ }^{2 *}$ \\ ${ }^{1}$ Indira Gandhi National Open University, Shyama Prasad Mukherji College for Women, University of Delhi, India \\ ${ }^{2}$ Associate Professor, Shyama Prasad Mukherji College for Women, University of Delhi, India
}

*Corresponding author: meenuag63@gmail.com

Received: $11-08-2018$

Revised: $18-11-2018$

Accepted: 06-12-2018

\begin{abstract}
The study was conducted to assess the dietary intake and nutritional status (in terms of anaemia and physical growth) of adolescents from high socioeconomic strata in Delhi. Factors affecting anaemia among subjects were also analyzed. Study was conducted on 100 adolescents in age group of $10-17$ years. The study revealed low intake of calories and very low intake of iron by adolescents. There were no economic constraints but various factors like convenience. Traditional practices and dietary beliefs appeared to influence the dietary intake patterns of subjects. It was found that 28 percent subjects were overweight, 68 percent had normal BMI while 8 percent were underweight. Only 23 percent were non anaemic and remaining had low or moderate anaemia. BMI for age was significantly correlated with calorie intake. Haemoglobin levels had no relation with BMI however they were significantly correlated with iron intake of subjects. A need for nutritional counselling was felt after completion of study so as to address problems of anaemia due to faulty eating habits.
\end{abstract}

Keywords: Anaemia, BMI, Haemoglobin, iron, nutritional status

Theword adolescencefrom the Latin word adolescence which means "to grow". It is a challenging phase in development. There is growth spurt and is associated with many changes. All these changes create special nutritional needs (Spear, 2002).

Adolescents face a risk of developing iron deficiency and suffering from anaemia. It is due to rapid physical growth during this phase plus additional iron losses in girls due to onset of menstruation (Fomen et al. 2003). They have increased need of dietary iron for haemoglobin and myoglobin as their blood volume and muscle mass is increasing.

In high socio-economic group strata there are no economic constraints, but various factors like convenience, traditional practices, and ignorance about dietary requirements, food fads, and consumption of junk foods may adversely affect their iron status as well as physical growth. Thus it is important to study dietary intake and nutritional status of adolescents from high socio economic strata also.

\section{METHODOLOGY}

The study was conducted on 100 adolescents from high socio economic strata residing in Delhi. A pre-coded and pretested interview schedule was administered to get the desired information. The dietary intake of subjects was assessed by 24 hours dietary recall and Food frequency questionnaire. The dietary intake of subjects was converted into energy, protein and iron using Nutritive value of 
Indian Foods. Iron status of subjects was assessed by analyzing level of haemoglobin in blood. Subjects were divided as non anaemic or in different stages of anaemia using WHO classification. Subjects were also examined for presence of clinical signs of anaemia. Anthropometric measurements (weight and height) were taken to assess their physical growth. $Z$ scores for BMI for age were calculated. Analysis was done find out correlation of various factors with anaemia using Pearson coefficient.

\section{RESULTS AND DISCUSSION}

Socio Demographic Profile of the Subjects: The study was conducted on 100 adolescents belonging to high socio economic strata. The age of subjects ranged from 10 to 17 years. Forty six percent were males and fifty four percent were females. Further, 43 percent subjects were aged between $10-12$ years, $35 \%$ were 12-14 years old while $22 \%$ were between $14-17$ years age group.

Parents of subjects were well qualified in general. It was found that with respect to qualification of father's, 22 percent were qualified professionals, 20 percent were post-graduates and 41 percent were graduates. Only 17 percent were only graduates. Regarding qualification of mother's 16 percent were qualified in professional courses, 14 percent were post graduates, and 48 percent were graduates whereas 22 percent were intermediates. All subjects were school students.

Dietary intake of the subjects: Dietary intake of subjects was assessed by 24 hours Dietary recall technique. The data collected was converted into macro-nutrients (energy and proteins) and micronutrient (iron). The mean intake of these nutrients were compared with RDAs (ICMR 2010). The data revealed that calorie intake was lower than the RDAs in all age groups and in both genders. This group had no financial constraints, still energy intake was lower than RDAs. There is need to further research into reasons for low consumption. However their diets were not deficient in proteins. Most of them were consuming adequate or more than RDA of proteins. Most of them were consuming milk and intake of pulses and eggs was also there. These factors were responsible for overall good quantity and quality of protein in their diet. The analysis of diet in terms of iron revealed intakes much lower than RDAs. In the survey conducted, $65 \%$ subjects had reported that they were non vegetarians, however analysis of diet by 24 hours dietary recalled reflected very low consumption of meat/ fish or poultry. Thus they were not getting heam iron. That was more a reflection of food habits rather than financial constraints. Rich sources of iron from plant foods like green leafy vegetables, sprouted pulses, whole pulses, millets etc. were consumed in very low amounts. The reasons were mainly related to dietary habits and ignorance about consumption of iron rich foods by subjects as well as their parents. Low intake of cereals, pulses and green leafy vegetables by adolescent girls was reported in a study in Madhya Pradesh (Tatia and Taneja, 2003).

Poor nutritional habits can have serious repercussions. They will not leave the adolescents with desired amount of energy required for interacting with others, participation in sports or simply feeling good about themselves (Rachel, 2010).

Haemoglobin Status of Subjects: The concentration of haemoglobin can provide information about the severity of iron deficiency. For this study, World Health Organization (WHO) cut-offs for defining anaemia were used (WHO, 2011). The age-wise and gender wise mean haemoglobin level in present study reflected that the mean haemoglobin level of subjects was lower than WHO cut offs for their respective ages (Table 1 ).

It was clear from data that mean haemoglobin values were lower than the WHO cutoffs. That reflected that anaemia was present in subjects. The haemoglobin of each subject was then also compared with the respective cut off of anaemia given by WHO. On the basis of this table (Table 2), subjects were classified as non- anemic, mild, moderate or severe anaemic.

Analysis of subjects' haemoglobin on the basis of this table revealed that none of the subjects had severe anaemia that is none of the subjects had 
Table 1: Haemoglobin status of Subjects (g/L)

\begin{tabular}{lllll}
\hline Age (years) & Male (Mean \pm SD) & $\begin{array}{l}\text { WHO cut- off for non } \\
\text { anaemic }\end{array}$ & $\begin{array}{l}\text { Female } \\
\text { (Mean } \pm \text { SD) }\end{array}$ & $\begin{array}{l}\text { WHO cut- off for } \\
\text { non anaemic }\end{array}$ \\
\hline $10<=12$ & $\geq 11.5$ & $\begin{array}{l}10.9 \pm 1.2 \\
(\mathrm{n}=25)\end{array}$ & $\geq 11.5$ \\
$12<=14$ & $\begin{array}{l}10.8 \pm 1.1 \\
(\mathrm{n}=18)\end{array}$ & $\geq 12.0$ & $\begin{array}{l}10.8 \pm 1.2 \\
(\mathrm{n}=19)\end{array}$ & $\geq 12.0$ \\
$11.2 \pm 1.1$ & & $11.3 \pm 1.6$ & $\geq 12.0$ \\
$(\mathrm{n}=18)$ & $\geq 13.0$ & $(\mathrm{n}=10)$ & \\
\hline
\end{tabular}

Table 2: Haemoglobin Profile

\begin{tabular}{|c|c|c|c|c|}
\hline Age Category & Non Anaemic & Mild Anaemic & Moderately Anaemic & Severely Anaemic \\
\hline 10-11 years & $\geq 11.5$ & $<11.5 \& \geq 11.0$ & $<11 \& \geq 8.0$ & $<8$ \\
\hline $12-14$ years & $\geq 12.0$ & $<12 \& \geq 11.0$ & $<11 \& \geq 8.0$ & $<8$ \\
\hline $\begin{array}{l}15 \text { years and above } \\
\text { females }\end{array}$ & $\geq 12.0$ & $<12 \& \geq 11.0$ & $<11 \& \geq 8.0$ & $<8$ \\
\hline $\begin{array}{l}15 \text { years and above } \\
\text { males }\end{array}$ & $\geq 13.0$ & $<13 \& \geq 11.0$ & $<11 \& \geq 8.0$ & $<8$ \\
\hline
\end{tabular}

(WHO, 2001).

haemoglobin level below $8 \mathrm{~g} / \mathrm{l}$. However mild and moderate anaemia was present in all age groups and both genders.

On the basis of this classification it was revealed that only $23 \%$ subjects were non anaemic. Mild anaemia was present in $23 \%$ subjects while another $54 \%$ were found to be moderately anaemic. Moderate anaemia was found more in girls in comparison to boys. A much higher level of anaemia (98 \%) among adolescents was reported in a large scale study done in rural Bangladesh (Shahabuddin et al. 2000). A study in Coimbatore reported $80 \%$ anaemia among children (Leela and Priya, 2002). On the other hand comparatively low level (34.4\%) of anaemia among adolescent girls (10-18 yrs.) was reported in a study in Meerut (Rawat, 2001). A study on adolescent girls (13-18 yrs.) in Manipur revealed that $35 \%$ were non anaemic while others were in different grades of anaemia (Kowsalya et al. 2008).

In the present study along with haemoglobin status, subjects were also examined to find presence of clinical signs of anaemia.

Print ISSN: 2319-3549
Clinical Symptoms of anaemia: Subjects were also examined to find presence of clinical signs of anaemia. Pale conjunctiva was observed in $12 \%$ subjects. All these subjects had moderate anaemia as per haemoglobin estimations. None of the subjects who were non anaemic or had mild anaemia showed pale conjunctiva. The difference in these three groups was found to be statistically significant as tested by chisquare (Table 3). Similarly in a study in Coimbatore on adolescents, pale conjunctiva was found to be an important clinical sign of anaemia (Swarnalata and Yegammai, 2006).

Pallor of eyelids was observed only in five subjects and all these had moderate anaemia. None of the subjects from non anaemic or mild anaemic group had pallor of eyelids. The differences were not statistically significant as tested by chi square.

In terms of other clinical signs of anaemia, $8 \%$ had pallor of tongue while pallor of nail beds and pallor of palms was observed in $6 \%$ and $3 \%$ subjects respectively. Difference in different groups in terms of these clinical signs were not found to be statistically significant as tested by chi square. Therefore, it 
Table 3: Clinical manifestation of iron deficiency anaemia

\begin{tabular}{lllll}
\hline Clinical Symptoms & $\begin{array}{l}\text { Non Anaemic } \\
(\mathbf{n}=\mathbf{2 3}) \\
\mathbf{n}(\mathbf{\%})\end{array}$ & $\begin{array}{l}\text { Mild Anaemic } \\
(\mathbf{n}=\mathbf{2 3}) \\
\mathbf{n}(\mathbf{\%})\end{array}$ & $\begin{array}{l}\text { Moderate Anaemic } \\
(\mathbf{n}=\mathbf{5 4}) \\
\mathbf{n}(\mathbf{\%})\end{array}$ & $\begin{array}{l}\text { Total } \\
(\mathbf{n}=\mathbf{1 0 0}) \\
\mathbf{n}(\mathbf{\%})\end{array}$ \\
\hline Pale Conjunctiva & $0(0)$ & $0(0)$ & $12(22.2)$ & $12(12.0)^{*}$ \\
Pallor of eyelids & $0(0)$ & $0(0)$ & $5(9.3)$ & $5(5.0)^{\mathrm{ns}}$ \\
Pallor of tongue & $2(8.7)$ & $0(0)$ & $6(11.1)$ & $8(8.0)^{\mathrm{ns}}$ \\
Pallor of nail beds & $0(0)$ & $0(0)$ & $6(11.1)$ & $6(6.0)^{\mathrm{ns}}$ \\
Pallor of palms & $0(0)$ & $0(0)$ & $3(5.6)$ & $3(3.0)^{\mathrm{ns}}$ \\
\hline
\end{tabular}

$X^{2}$ (chi square test), $n$ - non-significant; ${ }^{*}=$ significant $p<0.05$.

Table 4: Age-wise and Gender wise weight and height of the subjects

\begin{tabular}{llllll}
\hline Parameter & Age & $\begin{array}{l}\text { Males } \\
(\text { mean } \pm \text { SD) }\end{array}$ & $\begin{array}{l}\mathbf{9 5}^{\text {th }} \text { centile } \\
(\text { ICMR 2010) }\end{array}$ & $\begin{array}{l}\text { Females } \\
(\text { Mean } \pm \text { SD) }\end{array}$ & $\begin{array}{l}9^{\text {th }} \text { centile } \\
\text { (ICMR 2010) }\end{array}$ \\
\hline & $10-11$ & $39.4 \pm 6.2(\mathrm{n}=7)$ & 30.8 & $44.1 \pm 6.8(\mathrm{n}=11)$ & 31.2 \\
& $11-12$ & $43.2 \pm 6.5(\mathrm{n}=11)$ & 34.1 & $42.5 \pm 9.2(\mathrm{n}=14)$ & 34.8 \\
& $12-13$ & $45.2 \pm 8.8(\mathrm{n}=5)$ & 38.0 & $46.6 \pm 8.4(\mathrm{n}=8)$ & 39 \\
\hline Weight $(\mathrm{Kg})$ & $13-14$ & $52.8 \pm 3.8(\mathrm{n}=7)$ & 43.3 & $54.1 \pm 10.7(\mathrm{n}=8)$ & 43.4 \\
& $14-15$ & $55.5 \pm 5.6(\mathrm{n}=4)$ & 48.0 & $52.6 \pm 5.0(\mathrm{n}=3)$ & 47.1 \\
& $15-16$ & $54.8 \pm 2.4(\mathrm{n}=8)$ & 51.5 & $52.9 \pm 6.8(\mathrm{n}=6)$ & 49.4 \\
& $16-17$ & $54.8 \pm 2.3(\mathrm{n}=4)$ & 54.3 & $53.6 \pm 4(\mathrm{n}=3)$ & 51.3 \\
& $>=17$ & & $53(\mathrm{n}=1)$ & 52.8 \\
& 10 & $146 \pm 0.9(\mathrm{n}=7)$ & 140.0 & $145 \pm 0.9(\mathrm{n}=11)$ & 140.0 \\
& 11 & $144 \pm 0.9(\mathrm{n}=7)$ & 144.8 & $148 \pm 0.8(\mathrm{n}=14)$ & 145.3 \\
& 12 & $152 \pm 0.3(\mathrm{n}=5)$ & 151.1 & $153 \pm 0.7(\mathrm{n}=8)$ & 150.2 \\
\hline Height $(\mathrm{cm})$ & 13 & $159 \pm 0.6(\mathrm{n}=5)$ & 157.0 & $156 \pm 0.8(\mathrm{n}=8)$ & 153.8 \\
& 14 & $159 \pm 0.5(\mathrm{n}=5)$ & 163.0 & $158 \pm 0.5(\mathrm{n}=8)$ & 157 \\
& 15 & $161 \pm 0.8(\mathrm{n}=8)$ & 166.3 & $160 \pm 0.4(\mathrm{n}=6)$ & 158.8 \\
& 16 & $162 \pm 0.6(\mathrm{n}=5)$ & 168.3 & $160 \pm 0.7(\mathrm{n}=3)$ & 159.7 \\
& 17 & & 170.0 & $151(\mathrm{n}=1)$ & 160.2 \\
\hline
\end{tabular}

appears that pallor of conjunctiva is the best clinical sign to identify moderate level of anaemia in a field survey.

Data on Physical growth (weight and height) of the subjects: The data on height and weight of the subjects reflected that most of the subjects had anthropometric measurements at par with the $95^{\text {th }}$ centile of the ICMR, 2010 standards. This reflects that the children had satisfactory nutritional status (Table $4)$.

The data revealed that mean values of height and weight were comparable or higher than $95^{\text {th }}$ centile values of ICMR. It was clear that most of these adolescents were not undernourished in terms of height and weight. Some of them were rather overweight. In order to get a clearer picture BMI for age $\mathrm{Z}$ scores were also calculated.

BMI for age $\mathrm{Z}$ scores: From the data on height and weight of the subjects, BMI for age $\mathrm{Z}$ scores were computed using WHO Anthro plus software and compared to the gender and age specific norms of WHO, 2006. This data reflected that 28 percent subjects were overweight, 64 percent had normal BMI whereas 8 percent were under weight. Out of 
Table 5: BMI for age $\mathrm{Z}$ scores

\begin{tabular}{llllll}
\hline BMI Z Scores & Grade & $\begin{array}{l}\text { Non Anaemic } \\
(\mathbf{n = 2 3}) \mathbf{n}(\mathbf{\%})\end{array}$ & $\begin{array}{l}\text { Mild Anaemic } \\
(\mathbf{n = 2 3 )} \mathbf{n}(\mathbf{\%})\end{array}$ & $\begin{array}{l}\text { Moderately } \\
\text { Anaemic }(\mathbf{n = 5 4 )} \\
\mathbf{n}(\mathbf{6})\end{array}$ & $\begin{array}{l}\text { Pooled Data } \\
(\mathbf{n = 1 0 0 )} \mathbf{n}(\mathbf{\%})\end{array}$ \\
\hline +1SD to+2SD & overweight & $6(26.1)$ & $4(17.4)$ & $18(33.3)$ & $28(28.0)$ \\
+1SD to -1SD & Normal & $16(69.6)$ & $18(78.3)$ & $30(55.6)$ & $64(64.0)$ \\
-1SD to -2SD & Mild Underweight & $1(4.3)$ & $0(0)$ & $5(9.3)$ & $6(6.0)$ \\
-2SD to -3SD & Moderate Underweight & $0(0)$ & $1(4.3)$ & $0(0)$ & $1(1.0)$ \\
<-3SD & Severe Underweight & $0(0)$ & $0(0)$ & $1(1.9)$ & $1(1.0)$ \\
\hline
\end{tabular}

$X^{2}=9.587 ; p>0.05$.

Table 6: Pearson Correlation for finding factors influencing anaemia

\begin{tabular}{|c|c|c|c|c|}
\hline & & Haemoglobin & BMI & Iron \\
\hline $\mathrm{Hb}$ & $\begin{array}{l}\text { Pearson Correlation } \\
\text { Sig (2- tailed) }\end{array}$ & 1 & -.028 .779 & $.528^{* *} .000$ \\
\hline Age & $\begin{array}{l}\text { Pearson Correlation } \\
\text { Sig (2- tailed) }\end{array}$ & $\begin{array}{l}.195 \\
.052\end{array}$ & $\begin{array}{l}.313^{* *} \\
.001\end{array}$ & $\begin{array}{l}.059 \\
.558\end{array}$ \\
\hline Weight & $\begin{array}{l}\text { Pearson Correlation } \\
\text { Sig (2- tailed) }\end{array}$ & $\begin{array}{l}.248^{*} \\
.013\end{array}$ & $\begin{array}{l}.493^{* *} \\
.000\end{array}$ & $\begin{array}{l}.137 \\
.175\end{array}$ \\
\hline Height & $\begin{array}{l}\text { Pearson Correlation } \\
\text { Sig (2- tailed) }\end{array}$ & $\begin{array}{l}.233^{*} \\
.020\end{array}$ & $\begin{array}{l}.190 \\
.058\end{array}$ & $\begin{array}{l}.086 \\
.393\end{array}$ \\
\hline BMI & $\begin{array}{l}\text { Pearson Correlation } \\
\text { Sig (2- tailed) }\end{array}$ & $\begin{array}{l}-.028 \\
.779 \\
100\end{array}$ & $\begin{array}{l}1 \\
100\end{array}$ & $\begin{array}{l}-.091 \\
.368 \\
100\end{array}$ \\
\hline Calories & $\begin{array}{l}\text { Pearson Correlation } \\
\text { Sig (2- tailed) }\end{array}$ & $\begin{array}{l}.682^{* *} \\
.000 \\
100\end{array}$ & $\begin{array}{l}.205^{*} \\
.041 \\
100\end{array}$ & $\begin{array}{l}.603^{* *} \\
.000 \\
100\end{array}$ \\
\hline Protein & $\begin{array}{l}\text { Pearson Correlation } \\
\text { Sig (2- tailed) }\end{array}$ & $\begin{array}{l}.748^{* *} \\
.000 \\
100\end{array}$ & $\begin{array}{l}-.124 \\
.220 \\
100\end{array}$ & $\begin{array}{l}.500^{* *} \\
.000 \\
100\end{array}$ \\
\hline Iron & $\begin{array}{l}\text { Pearson Correlation } \\
\text { Sig (2- tailed) }\end{array}$ & $\begin{array}{l}.528^{* *} \\
.000 \\
100\end{array}$ & $\begin{array}{l}-.091 \\
.368 \\
100\end{array}$ & $\begin{array}{l}1 \\
100\end{array}$ \\
\hline
\end{tabular}

${ }^{*} p<0.05 ;{ }^{* *} p<0.01$.

these only one was moderately underweight and one was severely underweight.

In moderately anaemic group about $11 \%$ subjects were underweight while in non anaemic group only $4 \%$ were underweight. In non anaemic, mild anaemic and moderately anaemic group the percentage of overweight subjects was $26.1 \%, 17.4 \%$ and $33.3 \%$ respectively. All these differences between the three groups with respect to degree of malnutrition were non-significant as tested by chi square (Table 5).
It was clear from the results that presence or absence of anaemia did not significantly influenced another component of measuring nutritional status that is BMI for age. Various factors have been documented in literature which can have a bearing on status of anaemia.

Factors affecting anamia among Adolescents: In the present study data has been collected in terms of calories, protein and iron intake of subjects, as well as data about their height, weight, age BMI, 
haemoglobin level was available. An attempt was made to find factors affecting anaemia. These factors were treated by using Pearson Correlation to find out inter-effect of these variables.

In terms of haemoglobin, it was found that haemoglobin status did not correlate with age whereas with an increase in weight and height the haemoglobin status improved. Also with an increase in calorie, protein and iron intake haemoglobin increases. The results indicated the role of diet in improving haemoglobin and an adolescent with good weight and height is less likely to be anaemic (Table 6).

Relationship of nutritional status in terms of BMI for age indicated that BMI increases significantly with an increase in child's age and increase in energy intake. However, haemoglobin level of the subjects had no relationship with BMI of the subjects.

Iron intake of subjects was also found to be related with an increase in total calories and protein intake. It shows that a diet with sufficient amount of macronutrients (energy and protein) has a higher chance of meeting the micronutrient (iron) in comparison to a diet that is deficient in micronutrients. Iron intake was found to be significantly related with higher haemoglobin concentration.

The above study shows prevalence of anaemia in adolescents from high socio economic strata despite no constraints of affordability. This highlights need to make healthy choices for which nutrition education is imperative. Further poor nutrient intake among the study group especially in terms of energy and iron highlight immediate need for nutritional counselling which can address these problems.

\section{REFERENCES}

Fomen, S., Ransomel, Lopez, I.T. 2003. Anaemia among adolescents. Pediatrics, 107(6): 1381-1386.

Kowsalya, S., Crassina, A. and Shimaray. 2008: Impact of supplementation of lotus stem on the iron nutriture of adolescent girls (13-18 years) in Manipur. The Indian J Nutr. Dietet., 45: 47-53.

Leela, T. and Priya, S. 2002. Iron status and morbidity pattern among selected school children. The Indian J. Nutr. and Dietet., 21: 46-53.

Rachel Newcombe. 2010. Obesity in teens. European J. Clinical Nutr., 81(11): 757-763.

Rawat, C.M.S., Garg, S.K., Singh, J.V., Bhatnagar, M., Chopra, H. and Bajpai, S.K. 2001. Prevalence of anaemia among adolescent girls in rural area of district Meerut, UP. Indian J. Public Health, 45(1).

Spear, M.A. and Jenkins, S. 2002. Barriers that influence eating behavior in adolescents. Journal of Pediatric Nursing, pp. 234-67.

Swarnlatha, A. and Yegammai, C. 2006. Impact of iron, Vitamin $A$ and Vitamin C supplementation on anaemic adolescent girls. The Indian J. Nutr. and Dietet., 43: 229-237.

Tatia, R. and Taneja, P. 2003. Dietary intake of tribal adolescent girls of Dhar District in Madhya Pradesh. The Indian J. Nutr. and Dietet., 40: 344-347.

World Health Organization. 2001. Haemoglobin cocentrations for diagnosis of anaemia and assessment of severity. 